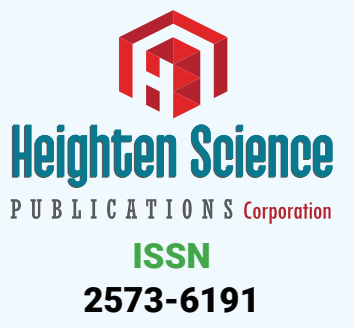

2573-6191
*Address for Correspondence: Malagón Hidalgo, Plastic and Reconstructive Department, Maxillofacial Surgery Department, Avenida Baja Velocidad, 284 Km 57.5, San Jerónimo Chicahualco, Metepec, Estado de México, Tel: 722-275-6300. Ext. 2062; Email:

hectormalagon@gmail.com

Submitted: 09 March 2017

Approved: 21 March 2017

Published: 23 March 2017

Copyright: @ 2017 Hidalgo M, et al. This is an open access article distributed under the Creative Commons Attribution License, which permits unrestricted use, distribution, and reproduction in any medium, provided the original work is properly cited

Keywords: Orbital floor fracture; Orbital floor reconstruction; Autologous costochondral graft; Titanium mesh; Poly-L-lactic acid/polyglycolic acid copolymer implant

\title{
Comparative Study of Enophthalmos Treatment with Titanium Mesh Combined with Absorbable Implant vs. Costochondral Graft for Large Orbital Defects in Floor Fractures
}

\author{
Malagón Hidalgo*, Héctor Omar, González Magaña, Fernando, \\ Kalach Mussali, Alberto Jaime, Mejía Valero, Sergio Abraham, \\ Vilchis López, Roberto, Araiza Gómez and Edgardo \\ Plastic and Reconstructive Department/Maxillofacial Surgery Department, Centro Médico \\ ISSEMYM, Toluca, México
}

\section{ABSTRACT}

Introduction: Several treatment options are available for the optimal treatment for orbital fractures, depending on aesthetic and functional results after orbital wall reconstruction. The objective of this study is to compare the effect and safety of large orbital floor fractures with titanium mesh combined with poly-L-lactic acid/polyglycolic acid copolymer implants (Lactosorb $®$ ) vs. autologous costochondral graft. A wide range of permanent and biodegradable materials have been used successfully for orbital floor reconstruction, however they present with disadvantages for reconstruction of large defects, even if combined.

Patients and Methods: A retrospective cohort study of patients from Estado de México, México, with access to ISSEMYM health care service, presenting with orbital floor fracture treated at Department of Plastic \& Reconstructive Surgery/Maxillofacial Surgery at ISSEMYM Medical Center Toluca between January 2007 and July 2010. Age, sex, etiology, clinical findings, fracture pattern, and treatment modality (Titanium mesh with absorbable implant vs. costochondral graft) were considered. Predictor and outcome variables as complications, inpatient, trauma- surgery interval, surgical time and donor site pain are considered.

Results: Follow up of 21 patients (12 weeks) 17 male, 4 female, ages 22-63 was made. Enophthalmos, main objective of this study, was identified with statistical significance presenting $0 \%(n=0)$ post-op Group $B$ patients and $30 \%(n=3)$ for Group $A(p=0.049)$. Statistical significance was found referring to inpatient days between two groups being less for costochondral reconstruction patients $(p=0.02)$. No pain in patients undergoing alloplastic surgery. An interesting result was that donor area analogue pain scale for costochondral graft was 2.9/10.

Conclusion: Surgical outcome and complications where evaluated comparing different materials for orbital floor reconstruction. Costochondral graft is a suitable choice when orbital reconstruction is indicated.

\section{INTRODUCTION}

Optimal treatment for orbital fractures depends extensively on a complete evaluations, determining the extent of the lesion and the beginning of a treatment at the optimal time, most orbital fractures are secondary to aggression trauma or car accidents, depending on population and place where it happens. Men are more frequently affected with this kind of fractures representing $18.3 \%$ of all face fractures, most of them between 11 and 50 years with a peak 21-30 years. The presentation can be as solitaire fractures but $70 \%$ of affected patient present a concomitant lesion. Approximately 50\% present another facial fracture, 22-30 \% present eyeball lesions. 
Surgical indications for orbital fractures are still controversial. Management for isolated blowout fractures is directed towards two principal treatable complications: eyeball position changes like enophthalmos and hypoglobus, and movement restriction secondary to entrapment of inferior rectus muscle [1]. Another indication is diplopia, especially when it does not solve after 2 weeks [2]. The most common indication for surgical reduction of orbital floor fracture is large defect, defined as more than $1 \mathrm{~cm}^{2}$ [2]. Larger defects are more prone to present enophthalmos if they are not treated, additionally any evidence of development of enophthalmos posterior to lesion requires intervention. If these lesions are not treated properly, they can cause severe aesthetic and functional complications like diplopia. Adequate treatment must provide appropriate structural support for orbital content and reestablish volume to restore physiological function and aesthetic appearance [1]. In presence of lesions where surgery is indicated, this can be performed immediately if patient conditions allow, or retarded 1-2 weeks until conditions are optimal [1].

With the continuous study of different materials for reconstructive surgery, synthetic versus autologous, election of implant and indications are still controversial, since they have depended extensively on surgeon's preference and chosen technique, comorbidities of donor area and prices of implants. Classically bone grafts are used, however, some new alloplastic materials have demonstrated adequate functionality. The ideal material would be one that restores volume, anatomic form, minimal absorption, easy placement, minimal or none inflammatory reaction, reproducible and do not cause morbidity sites. Titanium meshes, porous polyethylene implants and even absorbable plates have been used with different success rates from 75-93\%. Once the material is shaped with adequate size, implant must be placed all over the defect, sometimes needing fixation, but most of the times are already fixed by per-orbital tissues, anticipating that edema caused by injury is going to decrease, the procedure must contemplate an over correction, if this step is not done, reconstruction is not anatomic and it can produce enophthalmos after some weeks [3]. Recently, some results have been reported combining both categories of existing implants, permanent and absorbable ones, when treating large defects, and with this, getting benefits from both of them, presenting in some cases enophthalmos as a complication postsurgery. These results have not been compared using autologous tissues like cartilage with large defects; this can serve as a guide to determine which material can be the best to diminish the risk of this important complication [3]. Best treatment for post reconstruction enophthalmos is prevention at initial procedure [4].

Reported post-surgery complications using absorbable materials alone for reconstructive procedures of orbital floor are from 3 to $25 \%$ [5-9] and with synthetic materials are from 7.4 to $18 \%[10,11]$, this is talking about small defects mostly, however, there are reports with complications of $25 \%$ using titanium mesh combined with Lactosorb in large defects [11]. Combining these two materials prices raise, that is why the purpose of this study is to compare results using autologous material versus synthetic material plus absorbable implants for the reconstruction of orbital floor with large defects, and, determine superiority of costochondral graft making evident the improve with complication rates and recurrence of enophthalmos.

\section{PATIENTS AND METHODS}

This is a retrospective observational cohort study, comparing between independent groups, includes patients operated for elective reconstruction at Plastic and Reconstructive Surgery Department of Centro Médico ISSEMYM Toluca, located in Metepec, México, between dates January 2007 and July 2014.

Included patients presented large orbital floor fractures $(>$ or $=1.5 \times 1.5 \mathrm{~cm}$ ), isolated or in association with other facial fractures and orbital content was herniated to maxillary sinus with CT study, also enophthalmos $>$ or $=2 \mathrm{~mm}$ with exophthalmometry. 
Patients with eyeball trauma or injury were excluded because procedure was contraindicated. Elimination criteria included death of the patient.

Groups were divided as patients with surgery technique that included combination of materials (titanium mesh + Lactosorb $®$ ) as "Group A", and patients reconstructed only with autologous costochondral graft as "Group B".

Analyzed data includes sex, age, time between injury and surgery, hospital stay days, surgery time, donor site pain and complications including orbital and donor site. Donor site pain was inspected with analogue-visual scale from $0-10$ points at $24 \mathrm{~h}$, using same analgesic drugs based on acetaminophen $500 \mathrm{mg}$ every 8 hours per os, Ketorolac $30 \mathrm{mg}$ IV every 8 hours and Ropivacaine infiltrated during surgery in donor site. Follow up was 12 weeks with each patient at day 7, 21 and weeks 6 and 12, examining post-surgery enophthalmos, diplopia, eye movement restriction, ectropion and surgical scar at donor site.

For quantitative variables (age, time between injury and surgery, hospital stay days and surgical time) average was used, median and standard deviation making analysis with Student T. For dichotomus variables, frequency and proportions were used, and were analyzed with chi - quare and Fisher test according to every case. Statistical significance was considered with $\mathrm{P}$ values $<$ or $=0.05$.

\section{RESULTS}

This study included 21 patients from those: Group A (10 patients) and Group B (11 patients). There was no statistic significance with demographic variables like age (41.6 \pm 10.26 vs. $33.1 \pm 11.21 ; p=0.12$ ) (Table 1 and 2). More common cause of trauma was aggression ( $63 \%$ vs. $50 \% ; p=0.052$ ), and other less important like car crash and falls (Table 3). Male patients were more common in this study (81\%) than female patients (19\%).

Variables referring to time between trauma and surgery in days $(15.9 \pm 21.47 \mathrm{vs}$. $12.6 \pm 9.02 ; p=0.65)$ and surgical time in minutes $(102.2 \pm 54.7$ vs. $73 \pm 19.4 ; p=0.063)$ neither were significant. However, inpatient days $(1.36 \pm 0.50$ vs. $2.0 \pm 0.81 ; p=0.02)$ were statistically significant being less for costochondral reconstruction patients, one patient in Group A presented early enophthalmos after reconstruction, and it was corrected during the same stay (Table 3).

Post-surgery pain at donor site evaluated with analogue scale $(0-10)$ at $24 \mathrm{~h}$, showed an average of $2.9+/-1.13$ for group B, no pain for group A. Talking about presenting enophthalmos, main objective of this study, it was identified statistical significance presenting $0 \%(n=0)$ post op in patients of Group B and 30\% $(n=3)$ for Group A

\begin{tabular}{|c|c|c|c|c|c|c|c|}
\hline Patient & Years & Gender & Cause & Complication & $\begin{array}{c}\text { Surgical } \\
\text { time } \\
\text { (min) }\end{array}$ & $\begin{array}{c}\text { Trauma- } \\
\text { Surgery } \\
\text { interval } \\
\text { (days) }\end{array}$ & $\begin{array}{c}\text { Inpatient } \\
\text { (days) }\end{array}$ \\
\hline 1 & 55 & M & Aggression & Enophthalmos & 120 & 37 & 1 \\
\hline 2 & 26 & M & Car accident & None & 200 & 10 & 2 \\
\hline 3 & 36 & $\mathrm{~F}$ & Aggression & None & 90 & 12 & 3 \\
\hline 4 & 27 & $M$ & Aggression & None & 50 & 8 & 2 \\
\hline 5 & 23 & M & Aggression & None & 80 & 8 & 3 \\
\hline 6 & 22 & M & Aggression & Malar hematoma & 70 & 9 & 1 \\
\hline 7 & 30 & M & Aggression & None & 60 & 12 & 1 \\
\hline 8 & 49 & $M$ & Drop & Ectropion & 80 & 9 & 2 \\
\hline 9 & 39 & $\mathrm{~F}$ & Aggression & Enophthalmos & 70 & 16 & 3 \\
\hline 10 & 24 & M & Aggression & Enophthalmos + ectropion & 70 & 12 & 2 \\
\hline
\end{tabular}




\begin{tabular}{|c|c|c|c|c|c|c|c|c|}
\hline Patient & Years & Gender & Cause & Complication & $\begin{array}{c}\text { Surgical } \\
\text { time (min) }\end{array}$ & $\begin{array}{c}\text { Trauma- } \\
\text { Surgery } \\
\text { interval } \\
\text { (days) }\end{array}$ & $\begin{array}{l}\text { Inpatient } \\
\text { (days) }\end{array}$ & $\begin{array}{l}\text { Donor } \\
\text { site pain }\end{array}$ \\
\hline 1 & 52 & $\mathrm{~F}$ & Drop & None & 70 & 7 & 1 & 2 of 10 \\
\hline 2 & 38 & M & Aggression & None & 105 & 10 & 1 & 3 of 10 \\
\hline 3 & 36 & M & Car accident & $\begin{array}{c}\text { Thorax } \\
\text { hematoma }\end{array}$ & 40 & 9 & 1 & 3 of 10 \\
\hline 4 & 26 & $M$ & Aggression & None & 90 & 80 & 1 & 2 of 10 \\
\hline 5 & 22 & $\mathrm{~F}$ & Car accident & None & 150 & 8 & 2 & 4 of 10 \\
\hline 6 & 55 & $M$ & Drop & Thorax wound & 240 & 14 & 2 & 5 of 10 \\
\hline 7 & 33 & M & Aggression & None & 120 & 15 & 1 & 1 of 10 \\
\hline 8 & 63 & M & Drop & None & 60 & 7 & 1 & 3 of 10 \\
\hline 9 & 35 & M & Aggression & None & 70 & 12 & 1 & 2 of 10 \\
\hline 10 & 55 & M & Car accident & None & 80 & 8 & 2 & 4 of 10 \\
\hline 11 & 43 & $M$ & Aggression & None & 100 & 5 & 2 & 3 of 10 \\
\hline
\end{tabular}

Follow-up 7, 21 days, 6 and 12 weeks.

Table 3: Results.

\begin{tabular}{|c|c|c|c|}
\hline Year of age & $\mathbf{4 1 . 6 \pm 1 0 . 2 6}$ & $\mathbf{3 3 . 1 \pm 1 1 . 2 1}$ & $\mathbf{0 . 1 2}$ \\
\hline Cause (aggression) & $7 / 11(63)$ & $5 / 10(50)$ & 0.052 \\
\hline Trauma-Surgery interval days & $15.9 \pm 21.47$ & $12.6 \pm 9.02$ & 0.65 \\
\hline Surgical time (min) & $102.2 \pm 54.7$ & $73 \pm 19.4$ & 0.063 \\
\hline Inpatient (days) & $1.36 \pm 0.50$ & $2 \pm 0.81$ & 0.02 \\
\hline
\end{tabular}

Table 4: Complications.

\begin{tabular}{|c|c|c|c|}
\hline Presenting Enophthalmos & $0 / 11(0)$ & $3 / 10(30)$ & 0.049 \\
\hline Others & $3 / 11(27)^{\star}$ & $1 / 10(10)^{\star \star}$ & 0.31 \\
\hline Overall complications & $3 / 11(27)$ & $4 / 10(40)$ & 0.53 \\
\hline Donor site pain (EVA 0-10) & $2.9 \pm 1.13$ & & \\
\hline
\end{tabular}

( $p=0.049)$. Other kind of complications were identified with Group B related to donor site in $27 \%$ (hematoma, dehiscence and infection), and Group A in 10\% (ectropion), with no statistic significance $(p=0.31)$ between them. Total number of complications in both groups including recurrence of enophthalmos (27\% vs. $40 \%)$ did not reveal statistical difference ( $p=0.53$ ) (Table 4$)$.

\section{DISCUSSION}

Enophthalmos is caused by intraorbital area expansion secondary to fracture or atrophy of soft per orbital tissues, although more severe cases result from both. In consequence, repairing only augmentation of orbital area and taking it back to original size is not an optimal treatment, it also must include steps to increase volume of per orbital tissue or reconstruct a smaller orbit. However, to make fine adjustments to orbital tissue volume and size is difficult and is the biggest challenge when treating this kind of pathology [7].

Ideal synthetic material should be the one with adequate tensile force and structural stability, but at the same time, easy to manage to fit into desired shape, to have biological compatibility and that allows intravascular growth. Titanium is maybe the most used material for orbital floor fracture reconstruction, it provides adequate histocompatibility, it can easily be manipulated with an excellent structural support, but it is not perfect and it has presented late complications with the use of it. One of these complications is setting up adhesions described by Lee and Nunery [12], titanium forms a thin oxidized layer with air exposure, and this oxide allows fixation and proliferation of fibroblasts surrounding the implant, inflammatory cell adhesion is proportional to implant irregularities. 
Through the years, different synthetic materials and autologous tissue have been used for treatment of these kind of fractures, with subsequent benefits and disadvantages, however, until now, there is no consensus about which is the best material for orbital floor reconstruction considering volume too $[5,13,14]$.

It is evident that larger defect reconstruction requires implants with better resistance and rigidity for better structural support for orbital content. Talking about autologous materials, it has been used bone: skull graft, iliac crest graft; cartilage: nasal septum, ribs, auricular; however this materials present disadvantages like donor site morbidity, absorption rate, limited quantity, augmented procedure time and difficulty to shape it to the desired form, however they are more resistant to infections, no rejection and with good support and volume results [15].

Alloplastic materials are subdivided in permanent and absorbable. Permanent implants like hydroxyapatite, porous polyethylene and metals like titanium, have been associated to complications related to foreign body reaction, causing infection, extrusion, migration, eyeball movements restriction and consequent diplopia. Advantages like less surgery timing, limitless quantity and easy manipulation $[6,10,16,17]$.

Polylactic-L acid is hydrophobic and degradation resistant, meanwhile polyglycolic acid is hydrophilic and is quickly absorbed; combinations of these two kind of absorbable materials as unique and results in copolymer PLLA-PGA 82\%/18\% (Lactosorb). This copolymer has enough absorbable strength and characteristics with minimal foreign body reaction. Its mechanical strength lasts between two and three months and complete reabsorption until 9-15 months. Reabsorption is by hydrolysis, and this is other advantage because it does not produce inflammatory reaction $[8,18$ 21].

There is published evidence about efficiency and security of the use of Lactosorb with face bones and it has been used successfully for reconstruction of defects in orbital floor from small to medium sizes [21]. Other absorbable materials have been used with success but the common limitation of these materials is the risk of developing late enophthalmos because of the lack of adequate support of orbital content with large defects. Several experimented authors do not recommend its use with defects larger than $2 \times 2 \mathrm{~cm}$ larger defects or when orbital volume is altered, it is recommended a rigid permanent implant like titanium mesh or cartilage [20].

Combination of permanent rigid implant like titanium and absorbable material like Lactosorb seems ideal for reconstruction of large defects in floor defects. Combining these two materials the advantages of both are also summed up, and deficiencies are corrected. Titanium provides structural stability and adequate support for orbital content and Lactosorb absorbable implant minimizes risk of adhesion syndrome and its sequels, however it does not provides adequate volume if needed [22].

Patients who developed post-surgical enophthalmos after use of combination of both materials were also the same patients that had enophthalmos before surgery, these had to be re-operated to correct enophthalmos. Common denominator for these 3 cases was incomplete cover of the defect and incorrect placement of titanium mesh, and in one patient it was necessary placement of costochondral graft for solution of enophthalmos.

Autologous tissues were first materials used for orbital reconstruction and are still been used. These include a second surgical site, which increases patient mobility and requires in most of them an augmented surgical time to take graft. Some of these tissues are limited in quantity and have a variable absorption range with time. Absorption is non-predictable and late enophthalmos potential are the arguments more criticized with the use of autologous materials, particularly bone grafts and a cartilage grafts [23]. 
Autologous bone grafts have been Gold standard for making a frame in the reconstruction of facial bone and orbital wall fractures. Advantages represented are: good infection resistance, substitution for host bone, absence of rejection risk and low extrusion risk. However reabsorption and consequent volume reduction is the main enquiry after some time [23].Actually, skull bone seems to be the best option for orbital wall reconstruction, but iliac bone is still the preferred location.

Autologous grafts from iliac bone are an appropriate material for reconstruction and there's plenty of it, but it has augmented volume and it has to be reduced and the reabsorption rate is unpredictable. Tridimensional management and exact graft placement is extremely difficult and because of the reabsorption rate is high, it has to be overcorrected to allow for remodelation [23].

A lot of post traumatic enophthalmos cases, all of the orbital tissues, including optic nerve, eyeball and its muscles are displaced to posterior, and in consequence a more difficult treatment. To relocate these tissues to its original position, it is necessary to make the procedure in the posterior section of equator plane of eyeball and then move all tissues to an anterior situation. Placement of grafts with a solid consistence at a deep posterior position of equator eyeball plane increases the risk of augmented pressure on the eye and even optical nerve. Comparing, when cartilage graft is used, this can easily be molded into desired shape, reducing posterior area and adjusting to fit optimal orbital volume and filling area in multiple directions, maintaining tissue inside the orbit in balance without producing diplopia [7].

Placing costochondral graft in sunken areas and at an augmented size orbit, not only recreates an original size orbit but also produces increase in atrophied soft tissue, with fine volume adjustments with cartilage used to fill orbit, it's easier to adjust grade of eyeball projection minimizing the influence of graft material with eyeball and optical nerve [7].

Range of reabsorption in post-surgical graft tissue, talking about different kinds of autologous bone, is higher for iliac bone and recurrence is frequent. There are reports that recommend skull bone external plate with low reabsorption rate, but molding it into desired shape is difficult. Costochondral graft has a very low reabsorption range, and like skull bone, it has the effect of maintaining post-surgical eyeball position after being displaced into an anterior direction [7].

Complications reported for costochondral donor site are 5-20\% including pneumothorax, thoracic deformity, thoracic scoliosis and pathologic scar. Between the cases presented in this study, only one presented infected hematoma with wound dehiscence that was solved with drainage, wound cleaning and closure.

\section{CONCLUSION}

In this study we can substantiate that costochondral graft applied to large defects of orbital floor is superior to the combination of two alloplastic materials (titanium mesh + Lactosorb $\AA$ ), restoring orbital volume and producing adequate solution of enophthalmos with no recurrence and no restriction to eyeball movements, neither diplopia nor other orbital complication. Prices to use both alloplastic materials is eliminated without increasing hospital stay or surgical time prices in patients treated with autologous technique, although it's not necessary, we recommend two surgical teams, one for costochondral graft and other for orbital floor reconstruction, this will reduce surgical time. There was no need to re operate any of the costochondral graft group cases, however, donor site morbidity and complications do exist, but they can be avoided with careful technique. Pain was bearable in every patient with combined analgesic drugs without the need of opioids or increasing hospital stay. With this study we recommend to use costochondral graft technique as first option for large orbital 
floor defects reconstruction, this technique not only reconstructs defect, but also, restores adequate orbital volume. We considered that a prospective randomized study must be done with more patients and with only one surgeon involved to reduce bias and have a better sustentation of the obtained results.

\section{REFERENCES}

1. Chang EW, Manolidis S. Orbital Floor Fracture Management. Facial Plast Surg. 2005; 21: 207-213. Ref.: https://goo.gl/SrnDOP

2. Cole $P$, Kauffman $Y$, Hollier L. Principles of facial trauma: orbital fracture management. J Craniofac Surg. 2009; 20: 101-104. Ref.: https://goo.gl/7kgdP8

3. Magaña FG, Arzac RM, De Hilario Aviles L. Combined Use of Titanium Mesh and Resorbable PLLAPGA Implant in the Treatment of Large Orbital Floor Fractures. J Craniofac Surg. 2011; 22: 19911995. Ref.: https://goo.gl/JcdNyQ

4. Malagón Hidalgo H, González Magaña F, Rivera Estolano RT. Manejo del Enoftalmos como Secuela de Fracturas del Complejo Cigomático-Orbitario con Apoyo de Estereolitografía. Cir Plast Iberolatinoam. 2011; 37: 33-41.

5. Jank S, Emshoff R, Schuchter B, Strobl H, Brandlmaier I, et al. Orbital Floor Reconstruction with Flexible Ethisorb Patches: A Retrospective Long-Term Follow-Up Study. Oral Surg Oral Med Oral Pathol Oral Radiol Endod. 2003; 95: 16-22. Ref.: https://goo.gl/CuUKSQ

6. Custer PL, Lind A, Trinkaus KM. Complications of supramid orbital implants. Ophthal Plast Reconstr Surg. 2003; 19: 62-67. Ref.: https://goo.gl/7Xagan

7. Büchel P, Rahal A, Seto I, Izuka T. Reconstruction of Orbital Floor Fracture with Polyglactin 910/ Polydioxanon Patch (Ethisorb): A Retrospective Study. J Oral Maxillofac Surg. 2005; 63: 646-50. Ref.: https://goo.gl/2yvnwk

8. Tuncer S, Yavuzer R, Kandal S, Demir YH, Ozmen S, et al. Reconstruction of Traumatic Orbital Floor Fractures with Resorbable Mesh Plate. J Craniofac Surg. 2007; 18: 598-605. Ref.: https://goo.gl/Q8yhlk

9. Hollier LH, Rogers N, Berzin E, Stal S. Resorbable Mesh in the Treatment of Orbital Floor Fractures. J Craniofac Surg. 2001; 12: 242-246. Ref.: https://goo.gl/sNVBuC

10. Nam SB, Bae YC, Moon JS, Kang YS. Analysis of the Postoperative Outcome in 405 Cases of Orbital Fracture Using 2 Synthetic Orbital Implants. Ann Plast Surg. 2006; 56: 263-267. Ref.: https://goo.gl/zZSQWU

11. Hwang K, You SH, Sohn IA. Analysis of Orbital Bone Fractures: A 12-Year Study of 391 Patients. J Craniofac Surg. 2009; 20: 1218-12123. Ref.: https://goo.gl/o0EnAj

12. Mauriello JA Jr, Wasserman B, Kraut R. Use of Vicryl (Polyglactin-910) Mesh Implant for Repair of Orbital Floor Fracture Causing Diplopia: A Study of 28 Patients Over 5 Years. Ophthal Plast Reconstr Surg. 1993; 9: 191-195. Ref.: https://goo.gl/cSOJPu

13. Uygur S, Cukurluoglu O, Ozmen S, Guclu TH, Sezgin B. Resorbable Mesh Plate in the Treatment of Blow-Out Fracture Might cause Gaze Restriction. J Craniofac Surg. 2009; 20: 71-72. Ref.: https://goo.gl//BqOBZ

14. Ellis E $3^{\text {rd }}$, Tan Y. Assessment of Internal Orbital Reconstructions for Pure Blowout Fractures: Cranial Bone Grafts versus Titanium Mesh. J Oral Maxillofac Surg. 2003; 61: 442-453. Ref.: https://goo.gl//Kr39Cn

15. Kontio RK, Laine $\mathrm{P}$, Salo A, Paukku P, Lindqvist $\mathrm{C}$, et al. Reconstruction of Internal Orbital Wal Fracture with Iliac Crest Free Bone Graft: Clinical, Computed Tomography, and Magnetic Resonance Imaging Follow-Up Study. Plast Reconstr Surg. 2006; 118: 1365-1374. Ref.: https://goo.gl/IzIKG0

16. Park HS, Kim YK, Yoon CH. Various Applications of Titanium Mesh Screen Implant to Orbital Wall Fractures. J Craniofac Surg. 2001; 12: 555-560. Ref.: https://goo.gl/Q9HBCW

17. Xu JJ1, Teng L, Jin XL, Ji Y, Lu JJ, et al. Porous Polyethylene Implants in Orbital Blow-Out Fractures and Enophtalmos Reconstruction. J Craniofac Surg. 2009; 20: 918-920. Ref.: https://goo.gl/7QLqzl

18. Lee HB, Nunery WR. Orbital Adherence Syndrome Secondary to Titanium Implant Material. Ophthal Plast Reconstr Surg. 2009; 25: 33-36. Ref.: https://goo.gl/qzuqgf

19. Ng JD, Huyng TH, Burgett R. Complications of Bioabsorbable Orbital Implants and Fixation Plates. Ophthal Plast Reconstr Surg. 2004; 20: 85-86. Ref.: https://goo.gl/ghXclL 
20. Malagón-Hidalgo HO, González-Magaña F, Ayala-Ugalde F, García-Cano E, Vilchis-López R. Experiencia a largo plazo con el uso de implantes absorbibles preformados para el tratamiento de fracturas orbitarias. Cir Plast. 2015; 25: 97-105. Ref.: https://goo.gl/GwMm2j

21. Pietrzak WS, Kumar M. An Enhanced Strength Retention Poly (Glycolic Acid)-Poly (L-Lactic Acid) Copolymer for Internal Fixation: In vitro Characterization of Hydrolysis. J Craniofac Surg. 2009; 20: 1533-1537. Ref.: https://goo.gl/8AFss5

22. Ahmad N, Lyles J, Panchal J, Deschamps-Braly J. Outcomes and Complications Based on Experience with Resorbable Plates in Pediatric Craniosynostosis Patients. J Craniofac Surg. 2008; 19: 855-860. Ref.: https://goo.gl/zOkgv3

23. Kumar AV, Staffenberg DA, Petronio JA, Wood RJ. Bioabsorbable Plates and Screws in Pediatric Craniofacial Surgery: A Review of 22 Cases. J Craniofac Surg. 1997; 8: 97-99. Ref.: https://goo.gl/qUs8Mh

24. Losken HW, van Aalst JA, Mooney MP, Godfrey VL, Burt T, et al. Biodegradation of Inion FastAbsorbing Biodegradable Plates and Screws. J Craniofac Surg. 2008; 19: 748-756. Ref.: https://goo.gl/Yiyoqa

25. Eppley BL. Bioabsorbable Plate and Screw Fixation in Orthognathic Surgery. J Craniofac Surg. 2007; 18: 818-825. Ref.: https://goo.gl/JaFm97

26. Park $\mathrm{CH}$, Kim HS, Lee JH, Hong SM, Ko YG, et al. Resorbable Skeletal Fixation Systems for Treating Maxillofacial Bone Fractures. Arch Otolaryngol Head Neck Surg. 2011; 137: 125-129. Ref.: https://goo.gl/G7ZuJ6

27. Nunery WR, Tao JP, Johl S. Nylon Foil "Wraparound" Repair of Combined Orbital Floor and Medial Wall Fractures. Ophthal Plast Reconstr Surg. 2008; 24: 271-275. Ref.: https://goo.gl/vpVOJ6

28. Taban M, Nakra T, Mancini R, Douglas RS, Goldberg RA. Orbital Wall Fracture Repair Using Seprafilm. Ophthal Plast Reconstr Surg. 2009; 25: 211-214. Ref.: https://goo.gl/USNijd

29. Garibaldi DC, Iliff NT, Grant MP, Merbs SL. Use of Porous Polyethylene with Embedded Titanium in Orbital Reconstruction: A Review of 106 Patients. Ophthal Plast Reconstr Surg. 2007; 23: 439-444. Ref.: https://goo.gl/o6BtgC

30. Kontio R, Lindqvist C. Management of Orbital Fractures. Oral Maxillofac Surg Clin North Am. 2009; 21: 209-220. Ref.: https://goo.gl/QaSBRj

31. Clauser L, Galiè M, Pagliaro F, Tieghi R. Posttraumatic Enophtalmos: Etiology, Principles of Reconstruction, and Correction. J Craniofac Surg. 2008; 19: 351-359. Ref.: https://goo.gl/ulBiwO 